\title{
War News in Early Modern Milan: The Birth and the Shaping of Printed News Pamphlets
}

\author{
Massimo Petta \\ The Rise of Printed News: Negroponte and Ottava Rima Poems
}

The Milanese printing press made very early forays into the dissemination of news: one of the earliest printed texts in Milan was Lamento di Negroponte, a poem that narrated the siege and fall of the Venetian possessions in Greece some months after the event (12 July 1470). ${ }^{1}$ Though it was not the first to break the news to the Milanese public, this text continued to spread, after and alongside other oral and written media; a broad-range dissemination made possible by the advent of the printing press in particular. $^{2}$ From this point of view, it was similar to other contemporary wide-circulation poems, but the few cheap printed papers of the Lamento di Negroponte reported a fact that had happened recently: narrating an actual event, it merged entertainment and information. ${ }^{3}$ As for the narrative, this pamphlet did not launch a brand new textual typology, but rather followed an established genre, the chivalric poem, which was then about to experience an expansion thanks to the printing press. It provided the most suitable textual typology to spread accounts of events, giving them a collocation in an asymmetric intersection between oral and written

1 Lamento di Negroponte (Milan, 1471), USTC 999502. It is a ottava rima poem made of 46 stanzas distributed in 12 leaves in quarto and printed with roman letters. It was published by Antonio Zarotto on the behalf of Panfilo Castaldi between 15 March 1471 and 19 February 1472 , that is 8-19 months after Negroponte had fallen (12 July 1470).

2 "Catastrophes gave rise to an enormous and enormously varied body of texts. These included hastily composed eyewitness reports; poetic laments for the cities and their dead; humanist orations bewailing the barbarity of the Turks; learned tracts debating their origins and character.... Such texts both reflected and perpetuated the fevered contemporary debate over the problem of the terrible Turk. But the fall of Negroponte-or rather, public reaction to it - differed from any previous event in Italian history in one crucial way: it coincided almost exactly with the spread of printing through the major cities of the peninsula". Margaret Meserve, 'News from Negroponte: Politics, Popular Opinion, and Information Exchange in the First Decade of the Italian Press', Renaissance Quarterly, 59.2 (2006), pp. 440-80.

3 On this topic Lauro Martines, Strong Words: Writing and Social Strain in the Italian Renaissance (Baltimore: Johns Hopkins University Press, 2001), pp. 167-81.

(C) MASSIMO PETTA, 2016 | DOI 10.1163/9789004277199_013

This is an open access chapter distributed under the terms of the Creative Commons Attribution-

Noncommercial-NoDerivatives 3.o Unported (CC-BY-NC-ND 3.o) License. 
transmission, manuscript and print culture, between the 'great' and the 'little tradition.4

As for its reception, this pamphlet had a double appeal, thanks basically to its generally informative aspect on the one hand and its literary one on the other, which gave it the circulation and durability characteristic of a work of fiction. During the 1470 it was soon reprinted in Milan by Filippo da Lavagna (with the addition of a single stanza), then in Florence (more or less doubled in length to 95 stanzas) and in Naples (enlarged once more, to 105 stanzas); years later, in 1512 it reappeared in Milan, when Giovanni Castiglione reprinted the Florentine edition. ${ }^{5}$ This release was the forefather of a series of editions across Italy, which lasted until the 1620 s. Obviously, 150 years after the fall of Negroponte these later editions no longer had an informative function, but in the meantime war poems had achieved a large success. While its function as entertainment clearly emerged from the longevity of the text, its informative purpose was only germinal and would develop in the following publications over the years, especially in certain features which will become apparent below, such as the speed with which news spread and the paratextual marks of reliability. Both aspects of the text and its printed form would instead have concurred in favouring the integrity and especially the 'persistence' of the information among large publics, providing the necessary conditions for the news account to acquire a status autonomous from that of a generic account.

4 Borrowing the conceptual framework from anthropologist Robert Redfield, Peter Burke proposed the existence, at the beginning of the Early modern era, of a dual culture, in which coexisted and interacted a great tradition and a little one, of which the former belonged to the educated few ("transmitted formally at grammar school and at universities ... a closed tradition in the sense that people who had not attended these institutions, which were not open to all, were excluded") and the latter to the whole population, from the illiterate to the educated classes ("It was transmitted informally. It was open to all, like the church, the tavern and the market-place, where so many of the performances occurred"). Peter Burke, Popular Culture in Early Modern Europe (Farnham: Ashgate 2009), p. 55. Marina Beer described chivalric poems as "Genere di lunga durata e diffusione europea ... all'incrocio tra diffusione/ esecuzione orale-musicale e composizione scritta, tra destinazione popolare (per un pubblico non alfabetizzato ...) e destinazione colta (per un pubblico alfabetizzato ...)" ("an enduring and Europe-wide genre ... at the intersection between oral-musical dissemination/ performance and written composition, between popular targets (for an illiterate public ...) and cultivated targets (for a literate public ..."): Marina Beer, Romanzi di cavalleria (Rome: Bulzoni 1987), p. 17. On this topic also Marina Roggiero, 'I libri di cavalleria', in I libri per tutti: Generi editoriali di larga circolazione tra antico regime ed età contemporanea, ed. Lodovica Braida and Mario Infelise (Turin: UTET, 2010), pp. 23-41.

5 Lamento di Negroponte (Milan, c. 1472), USTC 999501; (Naples, c. 1480), USTC 999503?; (Florence, c. 1477), USTC 999504; and (Milan, 1512), USTC 800347. 
In any event, while war poems had a circulation comparable to a 'commonplace' fictional text, it was accepted that they were not original products of imagination, since they spread news about a real event, and printers consequently deployed specific paratexts aimed at emphasising their reliability. So in 1490 Lamento di Costantinopoli only provided information about the path of the news on which the poetic text was based:

\author{
Erano in quel tempo collegati \\ insieme li Sanesi e Vinitiani \\ equali mandaron messer Vital donate \\ a siena imbasciatore \& nelle mani \\ lettere vennon pe corrier mandate \\ rachontando lemorte de christiani. ${ }^{6}$
}

(By that time, were allied

Sienese and Venetians
the latter sent mister Vitale Donati
as ambassador to Siena
and there came to hand
letters sent by courier
accounting Christians' deaths.)

In contrast, two poems in 1515 provided lists of casualties as a paratextual apparatus, "non poetiche rassegne" (non-poetical parades), as Novati called them. ${ }^{7}$

In the meantime, from the late fifteenth century-coinciding with the Italian Wars - the release of this kind of narrative had become more frequent: around 1495 and once again in 1501 poems were published about the

6 Maffeo Pisano, Lamento di Costantinopoli (Florence, 1487, reprinted c. 1490), USTC 999513, 999512, fo. 6v. The poem was composed short after the event, on 30 July 1453: "Et nel tempo che disopra harai lecto | atrenta di di luglio raccontamo | dal principio alla fine come ho decto", fo. $6 \mathrm{v}$ ("And in the meantime of the facts above | I tell on the thirtieth of July | from the beginning to the end, as I said").

7 Simone Litta, La rotta de' Suizer facta in mezo Meregnano (Mondovì, 1515), ustc 800161, and Teodoro Barbieri, El fatto darme del christianissimo re (Venice, 1515), ustc 870192. Litta in Milan had published Opera nuovamente composta (Milan, $c$. 1501) about the Italian campaign of the King of France and had financed the florentine edition of a lamento ("ad petitione [on request by] di Simone da Milano") which dealt with "tucte le guerre state dalla edificatione di Roma sino al di presente": Giacomo Rossetto, Lamento de Italia diviso in capitoli septe (Florence, n.d.), ustc 853520. Francesco Novati, 'Poemetti volgari ignoti sulla calata di Carlo viII in Italia', Archivio Storico Lombardo, 15 (1901), p. 423. 
campaign of Charles VIII of France and, a few years later, a six-part saga about the early battles of the League of Cambrai (1509), which had diversified the landscape of printed wars. ${ }^{8}$ In particular, the poems of 1509 met the requirements of both the 'great tradition' and the 'little' one, since, on the one hand, proceeding from a humanist circle, they were aimed at cultivated audiences and, on the other, they introduced into battle poems a feature of the chivalry poem in general, namely a cyclic and serial nature. As for their material production, the first was composed and printed in the few days immediately after the battle of Agnadello, and the second introduced an innovative typographical element for this kind of narrative: an explanatory title, which explicitly enforces the informational function of the text ("cum tutti li successi \& accidenti varii de battaglie de giorni in giorni occorsi dopo la rotta de Agnadello, data a venetiani. Dove anchora se narra la destruction de li medesmi cum la perdita de tutto il gia lor stato ..."; "with all the events and various battle accidents, which happened day by day after Venetians' defeat in Agnadello. Moreover, is narrated their destruction, with the loss of the entire State"). ${ }^{9}$

Later, in conjunction with other pitched battles, new poems were released: a Venetian poem about Marignano was revisited and reprinted in Milan in 1515 and two poems were published a few years later, in 1522, about the battle of

8 L'armata del re di Francia (Milan, c. 1495), UsTC 996264, and Lamento di Roma fato novamente (Milan, c. 1501), USTC 762717. Two other pamphlets are doubtfully Milanese: Ercole C. Rinuccini, Istoria nova de la rotta e presa del Moro (Milan, c. 1500) and La guerra del Turco e presa di Modone (Milan, $c$. 1500) according respectively to Ennio Sandal, L'arte della stampa a Milano nell'età di Carlo V (Baden-Baden: V. Koerner, 1988), n. 669, and Caterina Santoro, Stampe popolari della Biblioteca Trivulziana (Milan: Castello sforezco, 1964), n.148. As for the six poems of 1509, they were attributable to a circle ("Ex Cripta Palladia Belloniana et Bielliana Claricianaque") whose identified members were Palladius Bellon and Girolamo Claricio: see Carlo Dionisotti, Scritti di storia della letteratura italiana (Rome: Edizioni di storia e letteratura, 2009), vol. 2, pp. 145-7. The first—La miseranda rotta de venetiani (Milan, 1509), USTC 801781 - was written 'Die xxii Maii M.D.IX' (explicit), while the battle took place on 14 May. Probably in the same year, it was reprinted in blackletter in Milan or in Rome by Eucario Sielber: see respectively Ennio Sandal, Editori e tipografi a Milano nel Cinquecento (Baden-Baden: V. Koerner, 1977-81), n. 678, and Alberto Tinto, Gli annali tipografici di Eucario e Marcello Silber (Florence: L.S. Olschki, 1968), n. 63. It was continued in La memoranda presa de Peschera (Milan, $c$. 1509), UsTC 801783, reprinted probably in Bologna by Giustiniano da Rubiera in 1510 (USTC 801837). Then we have the 'canto quinto' (as the incipit states): La prexa de Lignago (Milan, 1510), USTC 801838. The third, fourth and sixth cantos are missing.

9 La memoranda presa de Peschera cum tutti li successi \& accidenti varii de battaglie de giorni in giorni occorsi dopo la rotta de Agnadello, data a venetiani. Dove anchora se narra la destruction de li medesmi cum la perdita de tutto il gia lor stato (Milan, c. 1509), USTC 801783. 
Bicocca. ${ }^{10}$ In particular, the latter, Francesco Mantovano's Lautrec, showed more sophisticated editorial planning, since it was a four-part work, complete with title pages, which partook more of the nature of small books than contemporary pamphlets. It was also more markedly literary, since it was a dramatic text in the form of a dialogue, and, being an invective against Odet de Foix, its purpose was to take a political stand, rather than to recount an event.

In the second half of the $15^{20 s}$, Milanese printing suffered a deep crisis, connected both with the general crisis of incunabula and the devastation the city suffered during that phase of the Italian Wars. ${ }^{11}$ After normal production resumed, new ottava rima pamphlets concerning military events in the Mediterranean appeared, marking the continuity with previous publications but also introducing small updates and innovations. Firstly, a poem by Alessandro Verini narrating the events in the Mediterranean, especially the rescue of Corone (18 August 1533), was published a few weeks after the event: this was traceable news, as the pamphlet had a colophon and title page with author's name and places and dates of the events; moreover, the text began on the following page, indicating the fully paratextual nature of the title page (the colophon too was separated from the text). ${ }^{12}$ Two years later, in 1535 , when the army of Charles $\mathrm{V}$ conquered Tunis, the printer Vincenzo Meda released a booklet (48 leaves in octavo) and Verini published other serial poems in ottava rima, this time by himself. ${ }^{13}$ While several pioneering publications appeared in Rome in the meantime - such as newsletters from Tunis-Milanese printers followed the customary trend, producing 'traditional' pieces of print. ${ }^{14}$

10 El fatto darme del duca de Milano (Milan, c. 1515), USTC 802038, a revised edition-missing two octaves-of Barbieri, El fatto darme. About Bicocca: Historia de la victoria hauta novamente contra francesi suizeri e venitiani (Milan, c. 1522), USTC 802311; Francesco Mantovano, Nova inventione (Milan, c. 1522).

11 Simone Albonico, 'Recensione a Ennio Sandal', Rivista di letteratura italiana, 7 (1989), pp. $189-210$.

12 News arrived in Genoa on 4 September and the pamphlet was printed in Milan by Gottardo Da Ponte on 12 September. Alessandro Verini, La crudelissima rotta che ha dato Andrea Doria (Milan, 1533), ustc 862907.

13 Guglielmo Pansa, Historia nuova della guerra di Tunigi di Barberia (Milan, 1535), USTC 846507; Alessandro Verini, La gran rotta che ha dato la cesarea maestà, a Barbarossa (Milan, 1535), ustc 802705, is declared to be 'canto primo'. Gottardo Da Ponte published a booklet in octavo: Giulio Cesare Ripamonti, La vera guerra di Tunigi (Milan, 1535), USTC 852686: Sandal, L'arte, n. 50.

14 In Rome Francesco Minizio Calvo and Antonio Blado had published pamphlets with letters about military events already in $15^{26}$ (2), $15^{29}$ and 1532. In 1534 Blado printed a letter accounting the conquest of Tunis by Barbarossa. See Tullio Bulgarelli, Gli avvisi a stampa in Roma nel Cinquecento (Rome: Istituto di studi romani, 1967), nn. 7-8, 10, 12, 14. 


\section{The Coming of Pamphlets in Prose and the Standardisation of Layout}

In 1544 Francesco Minizio Calvo, who had moved from Rome to Milan, published an unprecedented account of the battle of Ceresole: it was a prose text written by Francesco Spina, a fiscal commissioner of the Empire, who joined the campaign of Alfonso d'Avalos, then Governor of Milan. Spina was a witness to the events and was well informed of the movements of the soldiers and their tactics, since he received punctual correspondence from many sites affected by the war. In fact, his goal was to demonstrate that criticism of Avalos' leadership was misplaced and the primary recipients of the text were clearly detractors who openly complained about the unfruitful outcome of the campaign. For his part, the printer tried to make the text appealing for a public larger than the one strictly involved in the debate: thus he added two woodcuts of the battle, even if these were not strictly necessary, in order to reinforce the communicative potential of the account. The resulting booklet was a very different product from previous examples of the genre: there was no entertainment, but pure detailed information, designed to sweep away any wrong idea about the campaign; in some respects it was akin to memorials, aiming at readers interested in politics rather than in amusement-information.

Although the Ceresole booklet was created with a specific intention, nonetheless it may have revealed the commercial potential of a battle account, especially a prose report. Three years later, in 1547, a Milanese printer published a purely informative, detailed eyewitness report of the battle of Mühlberg, a letter whose recipient was Ferrante Gonzaga, then governor of the State. ${ }^{15}$ Its title page can be considered a prototype of the crucial news genre of the avvisi that was consolidated over the following years: at the top it bore a precise title declaring its source ("Copy of a letter from Cesar camp translated from Spanish") and the event ("the very happy victory against the Duke of Saxony"), and a woodcut representing the ensign of the authority involved, in this case the imperial eagle between two columns.

Towards the middle of the century, then, different actors concurred in playing a role in the dissemination of news and in broadening the audience for it. The same printing presses multiplied both the informative correspondence and the verses of mountebanks and charlatans, who used to support their performances

15 Copia di una lettera venuta allo illustrissimo signor don Ferrante dal campo cesareo (Milan, 1547), USTC 803228. See Silvio Leydi, Sub umbra imperialis aquilae (Florence: L.S. Olschki, 1999), p. 87 . 
with printed pamphlets. ${ }^{16}$ The work of Paride Mantovano, a roaming mountebank active in Milan around 1551, testifies to the contamination between the genres: he published at his own expense verse pamphlets narrating battles, entertaining narratives based upon sources he claimed were reliable, 'guaranteed' by lists of casualties and prisoners, and in the meantime, he did not hesitate to publish a fictional text with a news-like title as well as a real prose news pamphlet. ${ }^{17}$ As further evidence of the mingling of genres, in 1559, after the battle of St. Quentin, an established printer like Francesco Moscheni released both an ottava rima poem by Frediano Lucchese (dedicated to Juan de Figueroa, the Governor of the State of Milan) and a Latin prose account aimed at a more specific audience, containing a list of people. ${ }^{18}$

In the second half of the century Milanese news production changed suddenly, and in a manner which it is not immediately easy to account for. According to Guerre in ottava rima (1988-9), a census of war poems in octaves, Milan saw 31 releases before 1566: after the unassailable Venice (leading, with 120), it was the second most significant Italian printing place for works in this genre, ahead of Florence (26), Bologna (26) and Rome (16); while elsewhere 'news poems' lasted a century longer, in Milan they disappeared as a genre from that year on. ${ }^{19}$ Around mid-century different actors began to play on the printed news stage: in just a few years, soldiers and ambassadors, occasional and professional writers, replaced mountebanks and poligrafi (authors who wrote in multiple genres).

In the second half of the sixteenth century, besides unknown or ephemeral operators, important printers began to work in the field of printed news, such

16 "A focus on performers who published or sold oral dissemination of texts in tandem with their printed the diffusion-suggests how broader publics, of every shade from illiterate to literate, were becoming acculturated to an expanding print culture": Rosa Salzberg, 'From Printshop to Piazza: The Dissemination of Cheap Print in Sixteenth-Century Venice', PhD thesis (University of London, 2008). Also Massimo Rospocher and Rosa Salzberg, 'Street Singers in Italian Renaissance Urban Culture and Communication', Cultural and Social History, 9.1 (2012), pp. 9-26.

17 On his behalf were printed, in verse: La felicisima vitoria auta dal s. principe d'Oria (Venice or Bologna, 1551), Ustc 803413, Lamento che fa Piero Strozzi sopra della rotta (Bologna, 1554), USTC 803661. In prose he published a tale, Copia de una littera venuta novamente dalla citta de Milano (Milan, c. 1551), USTC 803514, and a news pamphlet, Lordine della festa con la felice entrata (Rome, 1551), Ustc 803531.

18 Frediano Lucchese, La guerra di Picardia (Milan, 1557), ustc 830967, and Progresso della guerra di Picardia (Milan, 1557), ustC 803863. The latter booklet, rather atypical, contains two prose reports and also an index, two dedicatory poems, a list, an excerpt of Nostradamus' prophecy (bearing publishing data) in French, its translation and two celebrative sonnets.

19 Guerre in ottava rima (Modena: Panini, 1988-9). Actually the limit could be 1557, as thenceforth appeared only late reprints of Guerre orrende d'Italia (Venice, 1522). 
as Giovanni Battista Da Ponte, then co-owner of the oldest typographic enterprise in the city, who later-printing decrees and edicts-enjoyed the title of Royal Chamber Printer. Within a few years, following the trend, he had changed his mode of news production: while in 1554 he had published a poem about the conquest of Tunis, ${ }^{20}$ in $155^{8}$ he released a different kind of text, neither fictional nor literary but the transcript of a capitulation and a list of the forces fielded by the king of England (then Phillip II of Spain). ${ }^{21}$ The consolidation of the prose news pamphlets, so-called avvisi a stampa or relazioni, did not mark a sudden discontinuity with the previous production, but, on the contrary, several of its features lasted for long time. An early avviso of 1563 by Da Ponte concerning the battle of Dreux presented the events emphatically, in a fashion similar to the previous ottava rima poems, even if it bore an updated title page and was based on detailed and rapidly-dispatched report letters. ${ }^{22}$ Similarly, in 1564 the avviso of the Spanish capture of Peñon de Vélez de la Goméra published by Moscheni, despite being a detailed and updated-format report from an eyewitness, bore a title page underlining "la quantità delle galere, \& il numero dei soldati, con il nome, \& cognome delli Capitani" ("the quantity of the galleys and the number of the soldiers, with the names and the family names of the captains") in very similar fashion to the earlier battle poems. ${ }^{23}$ Moreover, the pamphlet contained an echo of fictional elements, in the form of a purported letter filled with threats from the emperor to the sultan. Along similar lines, in the same year of 1564 a booklet was published with news from the eastern Mediterranean, which nonchalantly mixed plausible information and fictional topics (for example the quarrel between two captains who met in the very same house to harass a woman-a literary topos-which caused 15,000 casualties). ${ }^{24}$ It is remarkable that its title page followed the emergent and recognisable pattern: at the top, an eloquent and catchy title declaring the

\footnotetext{
$20 \quad$ Vittorio Baldini, Il primo canto della guerra di Tunis (Milan, 1554), USTC 812056.

21 Il vero aviso del numero delle genti da piedi et da cauallo, delle artiglierie della armata (Milan, 1558), ustc 803965.

22 La gran vittoria di monsign. di Guisa, capitan generale dell'essercito catolico nel regno di Francia contra luterani; dove sivedrà distintamente la presa, \& morte de capi dell'una, \& l'altra parte; col numero de' morti dell'uno, \& dell'altro essercito (The great victory of Monseigneur of Guise, General Captain of the Catholic Army in the Kingdom of France against Lutherans; where it will be clearly shown the capture and the death of the leaders both ranks, with the number of the casualties of both armies; Milan, 1563), UsTC 801189.

23 La presa del Pignone et l'ordine che ha tenuto la maestà del re Filippo a prenderla, \& la quantità delle galere, \& il numero dei soldati, con il nome, \& cognome delli Capitani (Milan, 1564), ustc 804357 .

24 Flaminio Aspri, Copia d'una lettera venuta, dove si narra l'assedio (Milan, 1564), USTC 811345 .
} 
source, in the centre a xylographic vignette and the publishing data at the bottom. The publisher undoubtedly meant to offer this avviso as a reliable account of true facts (which it partly was), and therefore, since he had only old and very vague sources available, he released it in a "reliable form", trusting to the paratextual marks of reliability of the title page. As a matter of fact, the use of a recognisable avviso layout presented the text as the vehicle for a trustworthy message, an account of truly occurring facts, whose main source of interest for readers lay in its reporting of real events far more than in its literary quality, which was in fact fairly poor. ${ }^{25}$

In those years, the fight for supremacy in the Mediterranean provided materials for the growing niche market in printed news. The relative abundance of production favoured the standardisation of layout, which operated essentially in two directions: on the one hand, every printer's news and news-related production tended to grow ever more homogeneous and, on the other, avvisi printed in different cities became increasingly alike.

The need to reproduce an avviso as accurately as possible often pushed many printers in different cities to reproduce not only the text but the layout as well. So, when letters from Malta were published in all the major Italian cities, the printers sometimes maintained an identical title page too, even down to the xylographic vignette (the coat of arms of the Cavaliers). ${ }^{26}$ In Milan, Valerio Meda kept the same mise en page but used a different woodcut, a large one with an undefined battle engraved on it, very much in the style of an ottava rima poem, even if the text was a reliable daily account compiled from letters from Malta. ${ }^{27}$ As for the following events, in late October, Da Ponte spread the breaking news from Lepanto (via Venice) by an unusual broadside manifesto, suitable for placarding and very similar to the edicts he printed by appointment to the Governor. ${ }^{28}$ At all events, he had already released two 'regular' avvisi a stampa, one compiled from many short news items, the other proceeding from a letter, both of them with an up-to-date title page provided with the

25 Massimo Petta, 'Printed Funerals in 16th- and 17th Century Milan', in Routines of Existence: Time, Life and After Life in Society and Religion, ed. Elena Brambilla, et al. (Pisa: Pisa University Press, 2009), pp. 106-37.

26 Copia d'una lettera venuta ultimamente di Malta (n.p., n.d.), ustc 836987; Copia de una lettera (Bologna, 1565), ustc 801168; Avisi della levata de Turchi dallassedio (Naples, 1565), ustc 804373; Breve naratione di tutto il successo (n.p., n.d.).

27 Breve narratione di tutto il successo dell'assedio di Malta (Milan, 1565).

28 La stupendissima vittoria dell'armata christiana (Milan, 1571), USTC 804940. The text is the same reported in a manuscript avviso arrived to Rome published in Kenneth M. Setton, The Papacy and the Levant, vol. 4 (Philadelphia: American Philosophical Society, 1984), p. 1060. 
imperial eagle and the second with complete publishing data. ${ }^{29}$ This title page represented the final step in the standardisation process: the eloquent title, xylography and publishing data became its unfailing indispensable elements. All of them guaranteed reliability, providing information on the news: its source (eventually proclaimed as 'true'), the authority involved and the final producer of the text. Moreover, the standardised and repetitive title page became a benchmark for readers too: from that they learned to immediately recognise the news as such and more easily trust to its reliability.

Thus, a few years later, the Meda brothers' news title pages became strictly standardised and repetitive, even if they retained a hint of old-fashioned chivalry poems about them. ${ }^{30}$ The production of the Tinis also clearly moved towards uniformity. In ${ }_{1571}$ Pietro reprinted an account of the fall of Famagusta in a somewhat naïve fashion: he changed the title into a long one inflected with the terms of the earlier chivalric poems, emphasising the "cruel" nature of the siege, and the "new" capture; he also presented the protagonists as literary characters ("il Magnifico Bragadino") and used a generic woodcut of an unspecified battle by way of illustration. ${ }^{31}$ Instead, some years later, in 1585 ,

29 The treaty between Louis, Prince of Condé, and Henri II of France: Capitoli della pace tra la christianissima maestà del re di Francia \& il principe di Condè (Milan, 1558), ustc 830787; the forces of the English army: Il vero aviso del numero delle genti da piedi et da cavallo, delle artiglierie (Milan, 1558), USTC 803965; from Malta: Diversi avisi con li giorni distinti di molti assalti (Milan, 1565), USTC 801178; La presa di santo Ermo, estratto d'una littera scritta da Roma (Milan, 1565), ustc 804425.

30 Dechiaratione de tutti li successi et combattimenti, fatti tra il turco et il populo christiano (Milan, 1570), ustc 804719; Dechiaratione de tutti li avisi mandati di Spagna da la corte del re catholico (Milan, 1570), ustc 804718.

31 Nestore Martinengo, Il crudelissimo assedio et nova presa della famosissima fortezza di Famagosta (Milan, 1571), UsTC 841197. It was the reprint of a very popular account, L'assedio, et presa di Famagosta (Brescia, 1571), UstC 841194, whose releases across Northern Italy and Europe offer a clear image of the different usages of news-matter. The original report delivered by the captain Nestore Martinengo at his arrival in Venice was firstly published two times in Brescia (then under the rule of the Serenissima) and in Fano; it was also published as L'intiero ragguaglio del successo di Famagosta (n.p., n.d.). In 1572 Brescia edition was reprinted in Verona (S. and G. Dalle Donne, 2 editions) and Venice, with a more precise title: Relatione di tutto il successo di Famagosta (4 editions). In 1572, it was reprinted in London too (J. Daye), dedicated to Earl of Leicester; so far, it had lost its news format: actually, the addition of several paratexts (dedication, preface, description of the island, a poem in Latin and several notes) had converted it into a product different from pure news, aiming at a different, educated readership. It was also reprinted in Augsburg (M. Kriegstein, 1572) and in Paris (A. Wechel, 1572 and S. Nivelle, 1573). The German print was an exact translation (without either vignette or publishing 
Michele adopted an updated standardised pattern for his news publications: in the title page he used a concise and denotative title, which declared the source, the illustration and the imprint in full. Further circulation enforced the spread of the standard layout: his pamphlets were reprinted in other northern Italian cities, where this pattern was largely replicated. ${ }^{32}$ Conversely, the process of standardisation, by making printed news easily recognisable, favoured the wider circulation of this new genre. From about this time, the standardisation process was consolidated and further news pamphlets followed the established pattern. The normalisation of the title page proceeded hand in hand with that of the title itself. In the last quarter of the century it finally arrived at its durable form; it was not a generic title but rather a precise indicator of news-text with three basic distinctive elements: first, the source (avviso, relatione, copia di lettera etc.), then the event, and finally the original source and its author, omitted only if it was unknown or unavailable. Moreover, in cases of reprinting — often if a result of agreements between printers - the title page usually bore the indication of the first release. ${ }^{33}$

\section{The Seventeenth Century: Consolidation of the Standard and Proliferation of Variants}

In Milan, the emergence of Paolo Gottardo Da Ponte, official printer to the Royal Chamber Printer, in the field of news established a peculiarly close tie between 'official printing' (i.e. the printers entrusted to produce bans and edicts for the authorities) and news. From 1598, Pandolfo and Marco Tullio Malatesta-typographers specialising in popular literature-replaced the deceased Da Ponte, adopting the same semi-official title: they ran the enterprise along the lines laid out by their forerunner ${ }^{34}$ but developed the Royal

data in the title page); the French pamphlet, instead, was lightly edited: the list of casualties was replaced by two short advis, from Famagusta and Constantinople (via Vienna) aiming to enrich the text.

32 Nuovo aviso, e particolar discorso, della mirabile espugnatione d'Anversa (Milan, 1585), USTC 806o36, reprinted in Verona (S. Delle Donne) and Bologna (A. Benacci); Copia delli articoli, overo capitoli stabiliti, \& conclusi per la resa della città d'Anversa (Milan, 1585), ustC 805984, reprinted in Brescia (V. Sabbio), Bologna (A. Benacci), Genoa, Reggio Emilia (E. Bartoli) and Piacenza (G. Bazachi).

33 Massimo Petta, Networks of Printers and the Dissemination of News, in Specialist Markets in the Early Modern Book World, ed. Richard Kirwan and Sophie Mullins (Leiden: Brill, 2015) pp. $64-84$.

34 In the late sixteenth century Pandolfo also reprinted a 1523 ottava rima lamento: Lachrimoso lamento, che fa il gran mastro di Rodi (Milan, n.d.), ustC 802343. 
Chamber press specialisation in news matter, earning a high degree of trust from the Governors of the State over several decades.

For their news pamphlets, they did not introduce any significant innovations in layout, but fine-tuned existing norms, increasingly using the coats of arms instead of generic woodcuts in their avvisi title pages; they were also particularly concerned with the standardisation of their products, in order to make them easily recognisable as news, and specifically as reliable news: their news pamphlets, bearing a circumstantial explanatory title, a coat of arms (similar to the edicts) and their imprint in full, inspired confidence in their reliability on the part of both readers and the authorities. In other words, they offered a recognisable and reliable product, supported by the addition, on the printers' own initiative, the marks of the public authorities: that is, the caption of 'Royal Chamber' and the coats of arms, which unfailingly stood out on the title pages of news pamphlets. So, in 1613 Giacomo Ivagnes, Secretary of the Senate of Milan, ${ }^{35}$ addressed a newsletter to the printer:

M. Marco Tullio Malatesta. Essendo venuto alle mie mani l'inclusa lettera del successo felicissimo.... Ho voluto raguagliarvi subito, accioché possiate dare alla stampa qualche utile, et alla Christianità questa allegrezza, particolarmente in questo Stato, dove per quanto è amata S.M. nostro commun Patrone, et conosciuto questo Cavalliero [Ottavio d'Aragona Tagliavia, son of the ex-Governor Carlo] ... spero che doverà riceversi tal aviso con cordial affetto..... ${ }^{36}$

(Mr. Marco Tullio Malatesta. Since I received the attached letter of the very happy success.... I intended to inform you soon, so you can give the press some usefulness, and this exhilaration to Christendom, especially in this State, where, since His Majesty our common lord is loved and this knight is well known ... I hope this avviso will be received with cordial love....)

Relying on the market (which meant in practice conforming to the general trend and forming networks with other printers in several cities) and backed by the government, the Malatestas were able to increase their news production rapidly. Moreover, in addition to news they also released pamphlets containing the texts of treaties and settlements according to the standardised layout.

\footnotetext{
35 Ivagnes was grandson and great-grandson respectively of the secretaries of the Senate Iacopo and Giovanni Maria Cattaneo. Annamaria Monti, I formulari del Senato di Milano (Milan: Giuffrè, 2001), pp. 139-43. 
The prominent feature of their output of printed news was the quantity and the longevity of their production: they maintained their news publishing activity according to established patterns through several generations, and became a cornerstone of Milanese printed news over almost two centuries. Pursuing long-term familiar strategies and sticking to the norms they had helped to establish, the Malatesta family conferred continuity upon the Milanese pattern of printed news during the seventeenth and eighteenth centuries. ${ }^{37}$

Also partly thanks to the Malatestas, the consolidated layout of arvisi was maintained over the decades, even as the output increased enormously. During the seventeenth century increasingly efficient news networks granted the printers access to the abundant war news provided by the perpetual state of conflict; the growth of the output stimulated a differentiation of printed news matter, however, which took advantage of the fact that the process of standardisation had not erased all the textual variety of the first half of the sixteenth century, and finally enabled news to reach increasingly broad publics. ${ }^{38}$ This differentiation followed two basic patterns: the first aimed at keeping the consolidated format in order to convey different typologies of information texts; the second, by contrast, meant to introduce or resume variations to the avviso format.

\section{Different Texts, Same Layout: A Wide Range of Texts Set Up as News}

Following the first pattern, printers increased the production of settlements, short treatises, letters and all news-related texts that had occasionally been printed since the sixteenth century and published them according to the same layout as the avviso (to the extent of being almost indistinguishable at first glance). Soon a varied set of complementary news publications arose, presented as apparently homogeneous (in the sense of adopting the standardised layout of avvisi), a corpus which enriched the information and considerably extended the coverage of war events. The avviso format also applied to celebratory poems for victories and, sometimes, fictional stories about fantastic battles. As for the latter, usually printed by printers on the fringes of the trade and formally set up as reliable avvisi, they proposed the old-fashioned mix of imagination and reliability and thus revealed the capacity of the standardised layout to include different kinds of texts and to reformat them in the guise of "reliable news".

37 For this aspect, in 1621 and 1624 Giovanni Battista published news about the campaign of the King of Poland using a perfectly identical title-page layout: same woodcut and matching mise en page ('Nova, et Vera | Relatione' and 'Veridica | Relatione' were respectively the first two lines of the titles). Nova, etvera relatione della guerra trail potentissimore diPolonia, \& il Gran Soldano (Milan, 1621) and Veridica relatione della miraculosa vittoria (Milan, 1624).

38 Brendan Dooley, ed., The Dissemination of News and the Emergence of Contemporaneity in Early Modern Europe (Farnham: Ashgate, 2010). 
A sophisticated 1636 pamphlet about the "battle of the wasps" lay on the border between fiction and news. ${ }^{39}$ It took its cue from an episode after the battle of Tornavento: tormented by horseflies attracted by the decomposition of casualties, the French army had to abandon its position, not without a touch of sarcasm (they left the inscription "Quel che non hanno potuto gl'Ispani, lo hanno potuto i Tafani"; "what the Spaniards could not achieve, horsefly could")..$^{40}$ In fact the text was simply a satirical pro-Spanish reply to the 'ridiculous trophy', a cultivated invective against the French army, and did not relate any particular event: even the editor declared it to be merely a "Bassa Diceria di Vespe, o Moschoni" ("lowly chat about wasps or blue bottle flies"), indicating that it was essentially an entertaining text, the only mark of reliability being its avviso format. ${ }^{41}$

In 1676, the heirs of Antonio Malatesta-members of a collateral branch of the family and not Royal Chamber Printers - reprinted an account of an amazing battle of birds published in Venice and originally in L'Isle-sur-le-Doubs (Franche-Comté). They used the standard avviso format, in order to underline its nature as an account of a battle, and proclaiming its truthfulness ("Nuova, et verissima Relatione", as the title has it). Nonetheless, despite its apparent claim to reliability, the last words of the text vaguely reveal its fictional nature:

Sarei troppo lungo se volessi raccontare qui tutte le interpretationi, che si danno a un sì strano cuento, ma essendoli morti di tutte le spetie la più parte convengono che sia presaggio infallibile di guerre funeste, \& egualmente a tutte le Nationi. Iddio se ne preservi. ${ }^{42}$

39 Guglielmo Plati, Le Vespeide dell'Academico Caliginoso (Milan, 1636), reprinted in Cremona: Biblioteca volante di Gio. Cinelli Calvoli, vol. 4 (2nd edition; Venice, 1747), p. 539. Also Gregory Hanlon, 'Sources for a battle: Tornavento (22 June 1636)', in Battaglie. L'evento, l'individuo, la memoria, ed. Alessandro Buono and Gianclaudio Civale (Palermo: Associazione Mediterranea, 2014).

40 Girolamo Brusoni, Dell'Historia d'Italia (Venice: F. Storti, 1661), p. 135.

41 The pamphlet was commissioned by the Milanese bookseller Carlo Ferrandi, who dedicated it to Antonio Briceño Ronquillo, lord Chancelor of the State of Milan. He was a Spanish partisan: that same year, 1635, he financed Carlos García, Antipatia de' francesi, $e$ spagnuoli (Milan, 1635), then reprinted several times in Italy, in Bologna, Venice and Macerata, before 1702. Originally written in order to enforce the Franco-Spanish détente that followed the marriage of Anne of Austria and Louis XIII [La oposición y conjunción de los dos grandes luminares de la tierra (Paris, 1617; then Cambrai, 1622)], once the political atmosphere had changed, it was reprinted with merely the title modified and anti-French intention [La Antipatía de Franceses y Espanoles (Rouen, 1627 and 1630)]; Ferrandi in the dedication: Plati, Le Vespeide, fo. 2 r.

Nuova, et verissima relatione della battaglia delli uccelli (Milan, 1676), fo. $4 \mathrm{r}$. 
(It would be too long to recount all the interpretations given to such a strange account here, but, since there are casualties of every species, most people agree that it is an infallible omen of dreadful wars, affecting every nation equally. God spare us.)

Besides Milan, the French pamphlet reached England, where it was translated and published in Oxford. The presentation of detail this pamphlet is even more scrupulous: in the title page dates, places and sources are meticulously indicated. ${ }^{43}$ This account subsequently gave birth to a ballad, published on a London broadside, abandoning, in this case, any shade of reliability. ${ }^{44}$

Beyond fictional matter, one element in particular testified to continuity with the very early phase of printing news through the centuries: the lists of forces deployed and casualties sustained. Such paratextual additions appeared in ottava rima poems as early as the late fifteenth century and became increasingly common over time. ${ }^{45}$ In $155^{8}$ and 1571 pamphlets entirely dedicated to lists were published and, towards the last quarter of the century, it was not unusual to find them at the bottom of avvisi. ${ }^{46}$ There are numerous examples throughout the seventeenth century, but especially during the siege of Vienna this paratext reached its climax. ${ }^{47}$ Besides ordinary lists, when available, printers published detailed lists and even tables of every sort of goods,

43 A true relation of the prodigious battle of birds, fought in the lower region of the air, between the cities of Dole and Salinas, the 26th of February last 1675/6. According to the letters from Besanson, of the first of this instant March, 1676 (Oxford, 1676). The date ' $1675 / 6$ ' is a function of the Julian calendar, which remained in use in England until $175^{2}$.

44 The Frenchmens wonder, or, The battle of the birds (London, 1674-9). In England, another ballad concerning a battle of birds had already been published many years before, in 1621: see Hyder E. Rollins, A Pepysian Garland. Black-letter Broadside Ballads of the Years 1595-1639 (Cambridge: Cambridge University Press, 1922), pp. 150-4.

45 The title page of Pansa, Historia nuoua (1535) indicated that "si contiene ... il Numero delle Navi \& delle Galee \& parimente dell'essercito Christiano" ("it contains ... the Number of the Ships and the Galleys, as well as the one of the Christian army") even if actually there was no list in the booklet.

46 Il vero aviso del numero (Milan, 1558), ustc 803965; Dechiaratione de tutti li successi (Milan, 1570), USTC 804719; and Giovanni Battista Da Ponte's Il Bellissimo ordine dell'armata della Santa Lega (Milan, 1571), were essentially lists; those appeared, among the others, also in Breve narratione di tutto il successo (n.p., 1565); Il crudelissimo assedio (Milan, 1571), UstC 841197; Aviso della presa di Strigonia (Milan, 1595), usTC 819228; and Pandolfo Malatesta's Relatione nel seguito dell'impresa (Milan, 1598), USTC 807259.

47 Among the others, Narratione dell'essercito che di presente si trova in essere (Milan, 1632) has a particular arrangement, presenting a 'traditional' list followed by gazette news (i.e. synthetic dated paragraphs taken from a gazette) with a design that recalls Breve narratione di tutto il successo (1565). 
resources, forces and casualties. ${ }^{48}$ It is evidence of the strong consideration given to this kind of paratext that Marco Antonio Pandolfo Malatesta even apologised for not being able to publish a list, offering at least one 'sure' number:

Qui non s'include la Nota di tutte le robbe lasciate da' Turchi sotto Vienna, per non esser' ancora comparsa la veridica, e giusta, ma solamente vi è certezza, che il denaro trouato nel Padiglione del Gran Visir ascendi a due million di Reali da otto in tante Monete d'Oro. ${ }^{49}$

(The note of all the goods left by Turks under Vienna is not included here, since the true and correct one is not appeared yet, while is certain only that the money found in the pavillion of the Great Visir amounts to two millions of eight-Real pieces in golden coins.)

Beyond the maintenance of traditional elements, the most remarkable feature of the arviso format was its capacity to incorporate innovative elements, a versatility which was one of the main reasons of its success. During the sixteenth century, the avviso format was successfully applied to different kind of texts, especially pacts and treaties, which thereby achieved a format often identical to conventional reporting, despite not being reports in the strict sense: they did not bear news of the pact, but rather the text of the pact itself. On the theoretical level, they were of course deeply intertwined with politics and war, since without warfare they would not exist. In fact battle as such was not conceived of as a decisive event that could annihilate the opponent, but was rather an occasion to change the balance of the subsequent - often permanentpeace negotiations: armed struggle and negotiation were two inseparable aspects of a perpetual condition of conflict..$^{50}$ Thus, given the indivisibility of

48 Relazione compendiosa, ma veridica, di quanto è passato nel famosso assedio (Vienna, 1683).

49 Sincero, e distinto racconto de' consigli, \& operationi (Milan, 1683), p. 14. The promised list was published Distinta relatione della rassegna dell'essercito del gran turcho (Milan, 1683).

"War in ... in early modern Europe meant skirmishes and surprises far more than it meant full-scale sieges and battles, and the verdict of the latter could swiftly be offset by the debilitating drain of the former, prolonging the conflict.... But politics proved equally important in eternalising war. Above all, many of the issues for which early modern wars were fought defied an easy solution", Geoffrey Parker, 'Dynastic War 1494-166o', in The Cambridge Illustrated History of Warfare, ed. Geoffrey Parker (Cambridge: Cambridge University Press, 1995), pp. 159-6o. In 1636 Cardinal-Infante affirmed that "habbiamo risoluto di far entrare le loro Armi [of the Emperor and of the King of Spain] nel Regno di Francia non per altro, che per obbligare il suo Re a una vera, \& sicura Pace" ("we decided 
battle and negotiation, the layout of diplomatic information was often identical to that of generic news.

From the 1520s, before the consolidation of the avviso standard, presses began to publish the texts of diplomatic negotiations, which cluttered the early modern printed information landscape without cease. The earliest printed treaty in Milan was probably the Treaty of Madrid between Charles $\mathrm{v}$ and François I of 1526 and during the sixteenth century, the normal trajectory of treaty publication was analogous to that for news. ${ }^{51}$ In the first decades of the century their publication depended on occasional sources such as sovereigns' letters (and thus the texts were reported in letters or even, if in extracted form, in poems). By the second half of the century, however, the pact-text had gained autonomous status, its spread had become largely independent from direct dissemination by rulers' chanceries, and its publication increasingly punctual. ${ }^{52}$ In 1538 , in Milan, Gottardo Da Ponte published a pamphlet containing the essential text of the Truce of Nice and, many years later, in 1558, his heir Giovanni Battista published the agreements between Henri II of France and the Prince of Condé. ${ }^{33}$ In the crucial mid-century period, the increased diffusion of this kind of text and the direct involvement of Milan in European-scale events (such as the wars waged by the Spanish monarchy) concurred in stimulating the demand for punctual and detailed information, leading to the obsolescence of war-news poems and the quick decline of their production in

to drive the Armies in the Kingdom of France for no other reason but to force its King to a real and firm Peace"): Ferdinando per gratia di Dio Infante di Spagna (Milan, 1636), fo. 2r.

Littera mandata dalla Cesarea Maestà alla Republica et populo de Milano (Milan, 1526), USTC 836998 , written by Albertus Valdesius. The capitulations also arrived to Roman presses through several letters sent from Toledo and Madrid between 8 January and 11 February. Pace \& capituli fatte infra la C.M. \& lo christianissimo Re (Rome, 1526), USTC 836190; Aboccamento della maestà cesarea (Rome, 1526), USTC 802427; Lettere dela cesarea \& catholica maestà (Rome, 1526), USTC 836997, in Latin, and its translation into Italian Capitoli della santissima pace celebrata in Toledo (n.p., 1526), ustc 836188 . They appeared one year after the earliest printed pact: La pace e liga perpetua tra li principi re de Francia et re d'Inghilterra (Bologna, 1525), USTC 830783 . Years before a poem pamphlet about a peace had been published: Questa sie la tregua fata con limperatore (Venice, 1517), USTC 802182; Giancarlo Petrella, Fra testo e immagine. Edizioni popolari del Rinascimento in una miscellanea ottocentesca (Udine: Forum, 2009), pp. 161-3.

$5^{2}$ In 1530 in Bologna was printed a war poem in octaves regarding the seizure of Florence with the respective pacts: Ippolito da Ferrara, La guerra di Firenze \& quando si rese con gli patti e conventioni con la santita di nostro signor \& maesta cesarea. (Bologna, 1530), USTC 836565 .

53 Questi sono li capitoli de la tregua de dece anni (Milan, 1538), ustc 836193; Capitoli della pace (see n. 29, above). 
Milan. ${ }^{54}$ In the last quarter of the century the production of diplomatic news pamphlets became more and more regular: in the 1570 s and 1580 , printers published letters containing pacts from the Flemish theatre, adopting avvisi standards. In particular, in 1585 the Tinis published the capitulation of Antwerp using a layout identical to that used for the avviso announcing its fall (a title page bearing a framed lily woodcut bought from Pacifico Da Ponte)..$^{55}$ The Malatestas followed the same trend and, in 1598, they published the text of the peace of Vervins in the form of news. ${ }^{56}$ Besides war news and pacts, the avviso format was also used to spread 'declarations' and other statements to enforce claims over territories, aiming at creating a legal background to wars. In 1585, for instance, the pope's pronouncement against the legitimacy of Henri IV of France was soon published in Milan. ${ }^{57}$ The production of 'diplomatic matter' soon went far beyond the mere dissemination of pacts: since legitimacy was not a straightforward matter, especially during the war, contrary interests triggered cuts and thrusts about the legality of the various pretensions and the actual reasons for the campaigns, and skirmishes between cross-referenced royal declarations, manifestos and a wide range of pamphlets. In 1614-15 the Malatestas' presses kept up with the quarrels between the crown of France and Henri II, Prince of Condé, releasing five pamphlets of declarations, letters and replies. ${ }^{58}$ Then, in 1621 the heir of Da Ponte in Milan published an exhortation to the king of Spain to intervene in Valtellina, which Giovanni Battista Malatesta followed up with congratulations to the Governor Duke of Feria for his successful intervention and accounts of his specific victories; later another anonymous pamphlet begged the King of France to intervene in turn. ${ }^{59}$ Actually, as the

54 On the trajectory of the war poem production: Wilhelm Raymund, Italienische Flugschriften des Cinquecento (Tübingen: De Gruyter, 1996).

55 Editto perpetuo, qual viene a trattare dell'accordio, patto et conventione (Milan, 1577), USTC 857152. Alessandro Farnese, Copia d'una lettera scritta dal sig. prencipe di Parma generale in Fiandra (Milan, 1585), ustc 828815; Tinis' publications were Nuovo aviso, e particolar discorso and Copia delli articoli (see n. 31, above).

56 Capitoli, et conditioni della pace, et perpetua amicitia (Milan, 1598), USTC 830815.

57 Dichiaratione del santiss. N.S. Sisto papa V contra Henrico di Borbone (Milan, 1585), USTC 856606 .

58 Lettera del prencipe di Condè, scritta al rè christianissimo (Milan, 1614), Dichiaratione del rè christianissimo contra il prencipe di Condè (Milan, 1615), Manifesto del re christi.mo di Francia, sopra la detentione (Milan, 1615), Risposta della reina christianissima, reggente, madre del re di Francia (Milan, 1615), Lettera del Re mandata al Parlamento di Parigi sopra la causa della ritentione (Milan, 1615).

59 Alberto Pecorelli, Deploratione della Valtellina a' i prencipi catholici (Milan, 1621); Cherubino Ferrari, Elogio a perpetua memoria et a gloria immortale (Milan, 1621); Descrittione generale del lamentabile stato nel quale si trovano al presente (1622). 
speech of Phillip IV to the Great Council of Mechelen proved, the dissemination of printed texts could be the first step of political-military plans:

Essendosi [count Hendrik van den Bergh] portato così avanti nelli suoi pernitiosi, e cattivi consigli con havere ... pubblicato un numero grandissimo de biglietti, e manifesti, fatti spargere in molti luoghi, così fuori, come dentro di questo paese....60

(Since count Hendrik van den Bergh drove forward his harmful and evil plans as far as ... he published a great amount of flyers and manifestoes, disseminated in many place, both out and in this country....)

In general, the medium of print was very well suited to staking claims to authority or rule, but the avviso layout in particular was often used since it enabled the shading of 'pretension' into 'fact': doubly so if it bore the stamp of authority in the form of the mark of the Royal Chamber press.

Besides news and diplomacy, the constant growth in the output of warrelated texts stimulated a varied production aiming at different publics, including cultivated ones. Thus a diverse corpus of pamphlets and booklets flourished, offering information about everything that was 'complementary' to the event. In spite of being presented as apparently homogeneous-i.e. adopting the standardised layout of avvisi - this was actually a heterogeneous set of publications calibrated to reach specialist publics. Thus, in 1620 Marco Tullio Malatesta published a "Description of the Alps and the passes suitable for armies", which was formally identical to an avviso, even if it provided neither news nor further elaboration of particular events but simply described passes suitable for the passage of armies: the printer adopted a standard that was amenable to soldiers, who were the intended readers. ${ }^{61}$ In some cases, under a standard title page, the pamphlets had a larger-than-usual number of pages, which allowed the publishers to put forward, instead of information in the usual sense, in-depth dissertations about the events or collateral information fit for specialist readers. Melchiorre Malatesta in 1625 put the point clearly in introducing the avviso-like description of the site of Breda, titled 'Ragguaglio':

Uscì dalla mia Stampa pochi giorni sono la copia d'una lettera, con la quale scrivendo uno dal campo sotto Breda ad uno suo amico l'avvisava, come s'era resa quella piazza. Soddisfece questo ragguaglio in qualche

6o Parte presa nel Gran Consiglio de Malines (Milan, 1632), fo. 1r.

61 Giovanni Giacomo Conturbi, Breve descrittione dell'Alpi (Milan, 1620). 
parte, ma non in tutto alla ragionevole curiosità non tanto del popolo, quanto delle persone amiche delle storie, esperimentate nell'arte militare, $e$ pratiche de' Paesi di Fiandra, perché desideravano havere minuta contezza del sito di questa Villa.... ${ }^{62}$

(A few days ago there went forth from my printing press the copy of a letter from someone writing from the camp near Breda to a friend of his, advising him about the surrender of that place. This account satisfied partially, but not totally, the sensible curiosity, not of the people, but rather of the friends of histories', skilled in military art, and conversant with Flanders, because they wanted to have a precise account of the situation of this town, of the way the earls of Nassau gained it....)

Besides specialists, war information also targeted educated readers: in 1637 a Malatesta avviso, after the text taken from a gazette, contained a paragraph in Latin ("Extractus litterarum ex Cancilleria Magontinensi", or "Excerpt from the letters from Mainz's Chancery"). ${ }^{63}$ From the same publisher, an account of 1648 events in Bohemia was a little longer than usual (it ran to 20 pages), since it did not aim at offering the news of a single fact, but rather an ample and precise description of all the events that occurred from 26 July to 26 August. Moreover, it was dedicated to an eminent personality (the dedication replaced the coat of arms in the title page), since it could boast a superior complexity, containing several paragraphs in Latin. ${ }^{64}$

The wider public was not neglected by these 'news complements', as we might call them, particularly when they had a celebratory character. Not limiting themselves to specialised publics, they tried rather to involve the largest audience possible: some were even composed in dialect, such as the Bradaineida and Navarrineida, whose mock-heroic titles recalled epics. Printed by the Royal Chamber Press, these two mountebank poems, early examples of bosinate, were composed respectively to celebrate the capture of Breda and to make a fool of the pro-French faction ("navarrini"). ${ }^{65}$ Years later a prose work in dialect was composed to celebrate a Spanish victory in Lerida: even if it was

\footnotetext{
62 Breue ragguaglio del sito, e positura della villa di Bredà (Milan, 1625), p. 3; italics mine.

63 Prosperi successi dell'arme austriache (Milan, 1637) by Giovanni Battista Malatesta.

64 Breve raguaglio della sorpresa di Praga; et altre cose accadute (Milan, 1649).

65 This genre came to be appreciated in cultivated environments too: Dante Isella, 'Un accademico della Valle di Blenio: Bernardo Rainoldi' in Forme e vicende, ed. O. Besomi et al. (Padua, 1988), pp. 195-209. Andrea da Milano, Raggionamento fatto in lode di Bredà di Porta Noua. Bradaineida (Milan, 1625) and Descors intorna a la resa de Brada, Navarineida (Milan, 1625).
} 
in Milanese dialect, it was a dialogue between Roman talking statues, Marforio and Pasquino, evidently familiar figures among the Milanese public. ${ }^{66}$

In some cases of partisan publications, it is worth noting that printers sometimes preferred anonymity, which was mainly achieved in two ways: first, and most obviously, by omitting imprints, and secondly by avoiding recognisable layouts, and so releasing pamphlets similar to avvisi but without the title pages that were perceived as the recognisable element of the genre.

\section{Same Texts, Different Layouts: Variations of the Formats of News Matter}

The broadening of the output of printed news during the seventeenth century did not consist only of offering different products with identical layout. Following a different pattern, printers widened the supply of printed news by introducing variations to the avviso layout. These variously fulfilled the need to mark the difference of those texts from standard avvisi, or to vary the output in order to provide more appealing products.

So far we have seen the first pattern of differentiation of printed news matter stimulated by the growth in production: that is to say, the conservation of one consolidated format while conveying different typologies of information; the second, by contrast, called for variations to the arviso format to broaden the types of printed news output. As a result, while the trend from the midsixteenth century was towards standardisation of format, nevertheless the production of non-standard texts continued, in some cases following and updating the patterns that emerged during the sixteenth century, and, in several cases, introducing new kinds of products. Moreover, the increase of news circulation stimulated the production of different kinds of reports that were not reducible to avviso format.

In some cases technical constraints contributed to the variations. A title page in folio format takes more space than it does in quarto: this, together with broad margins, was suitable for publishing short sources, which had to be released quickly because of growing competition, without waiting for further news. ${ }^{67}$ In many other cases, however, the reason for adopting the folio format

66 Discors faa da Marfori e Pasquin sora l'assedi de Lerida (Milan, 1647). See Francesco Predari, Bibliografia enciclopedica Milanese (Milan, 1857), p. 380.

67 Relacione della rotta data all'essercito del marescial di Sciatillon (Alessandria, 1641), reprint of a Milanese edition, bore few lines of text and then only a list of casualties: it was followed by a detailed Nuova, e piu distinta relatione della vittoria (Milan, 1641) by the Malatestas. Their Copia di lettera scritta da Venetia il 19 corrente (Milan, 1649), in folio, narrates events that followed the battle of Fochies (12 May 1649). The note "19 of this 
seems to lie in the will to differentiate the output, introducing catchy title pages to attract attention. ${ }^{68}$ Moreover, the numerous Spanish news pamphlets circulating in Milan, which were typically laid out in folio format with no title page, may have had some influence.

As for the first case, the apparition of serial news may have suggested the need to mark a difference from standard avvisi. In Milan this first appeared in the 1630s: in military matters, even without a planned periodical release, the rapid succession of the events of the Thirty Years War and the growing regularity of the reports often made it highly desirable, if not always necessary, to know the previous news: such a situation had paved the way for an explicit seriality of news. The earliest specimen of this kind of avviso, published in 1635 by Giovanni Battista Malatesta, was entitled First account (Prima relatione), promptly followed by the Second: they adopted an unusual four-pages-in-folio format without title page, probably to emphasise the difference between this text and ordinary avvisi, and they adopted the same layout in both issues. ${ }^{69} \mathrm{~A}$ few months later they also published a Continuation, which confirmed its serial nature since the first words of the text: "Doppo l'avisato acquisto fatto da Spagnuoli della piazza di Corbey ..." "After the already accounted conquest of the stronghold of Corbey by Spaniards ..."). ${ }^{70}$ Later, in 1650, the Malatestas released two pamphlets concerning the capture of the Porto Longone fortress: the first was an avviso published in folio reporting the events and the second - having the same format, without title pages — contained the capitulation pacts: in this way they underlined the continuity between the two releases. ${ }^{71}$

Sometimes avvisi replicated the format of gazettes: although there is no shortage of evidence testifying to mistrust towards gazetteers ("Tutti quelli c'hanno senso commune giudicano, che se quel scritto viene à notitia de superiori del Gazettiero, non possono di manco, che confinarlo in casa de Pazzi ... e questo si deue alla riputatione de Scrittori publichi"; "Anybody who has common sense consider that, if gazetteer superiors become acquainted with that paper, they cannot help but put him away in a madhouse ... and it is due

month" (probably June) indicates that the pamphlet was conceived for an immediate consumption (within the month).

68 Relatione breve, e verdadiera de i felici progressi (Milan, 1636).

69 Prima- and Seconda relatione del seguito di Fiandra (Milan, 1635).

$70 \quad$ 1636. Adi 24. Settembre. Continuatione de i felici progressi (Milan, 1636), fo. $1 v$.

71 Relatione dell'uscita francesi Porto Longone (Milan, 1650) and Capitolatione per la resa di Portolongone (Milan, 1650). In 1662 in Naples news from Spain had several 'serial issues': Terza relatione diaria del progresso (Naples, 1662) and Quarta, e quinta relatione diaria de' progressi (Naples, 1662). 
to the reputation of public writers") in fact gazettes were occasionally used as sources. ${ }^{72}$ Sometimes the news was incorporated in avviso format, but often the printed sheets imitated the layout of the original gazette (no title page, and short paragraphs bearing the place and the date of the original news) $\cdot{ }^{73}$ It seems no coincidence that the earliest Italian printed gazettes appeared around this time: in Milan they were printed by the Malatestas from 28 November 1640 at latest. ${ }^{74}$

If the news was not to appear quickly, it was important that the text should have different appealing features. ${ }^{75}$ Thus, after the siege of Cremona was over, it was reported in a news text of an unusual kind, a synthetic day-by-day account with a few lines dedicated to it each day, which provided a global reconstruction of events. As the author remarked in the preface, the underground manoeuvres did not only make this task very difficult, but also left space for imprecise and unreliable news, which by then were considered fit matter for poetry: "Per essersi lavorato sotto terra ad usanza de topi, pare data più materia a versificatori de poemi, che certezza ad historici di penetrar il vero" ("Since they worked underground, like mice do, it seems that versifiers obtained more material for poems, than historians certainty for penetrating the truth". $)^{76}$

\section{The Siege of Vienna and the Explosion of Printed News}

In the last decades of the seventeenth century, the siege of Vienna triggered the flourishing of printed news: in that instance printers did not introduce

72 Relatione delle allegrezze fatte all'Haya in Olanda (n.p., 1598), fo. 2 r.

73 Relatione della resa di Ruremonda (Milan, 1637) by G.B. Malatesta, for an example in avviso form; for the latter case see for example Avisi sicuri da piu parti (Milan, 1635), Breve racconto di quanto è successo nell'aggiustamento di Napoli (Milan, 1648), Dal campo Regio sopra Beresteczko (Milan, 1651), all by the Malatestas; a couple of Spanish pamphlets by the same printers stand out: Relacion de varias cosas sucedidas (Milan, 1632) and Relacion de lo sucedido Biernes (Milan, 1650).

74 This gazette, printed by the Malatestas, was released weekly on Wednesdays at least until 28 December 1644. Pierangelo Bellettini, 'Le più antiche gazzette a stampa di Milano (1640) e di Bologna (1642)', Bibliofilia, 100.2-3 (1998), pp. 465-94.

75 La più difusa, e vera relatione d'ogn'altra; hauuta di Londra per mezo di soggetto molto qualificato (Bologna: C. Zenero, 1649) consisted of 32 pages that accurately described the trial and the execution of Charles Stuart.

76 Relatione sommaria di quanto è successo sotto Cremona (Cremona, 1648), fo. 1v. It was soon reprinted by the Malatestas (Milan, 1648). 
novelties in the patterns of publishing, but rather followed the lines traced during the preceding decades, taking the volume of printed information to an unprecedented level. ${ }^{77}$

Among standardised uniform publications, printers sometimes introduced variations to the layout of the avviso to vary the output, probably to extend the appeal to broader audiences. In 1683 the letter by Carlo Mattesilani was published in Milan and several Italian cities respecting the standardised format: eight pages in quarto and a title page with a woodcut (the imperial eagle) and imprint. Instead, in Florence the same text was published in folio with no title page and with the editorial data at the end. ${ }^{78}$ In Mantua the layout of the list of the forces of the Ottoman army was changed. ${ }^{79}$

In 1683, besides numerous eight-page avvisi, Marco Antonio Pandolfo Malatesta released a 'daily account' somewhat longer than usual (28 pages). ${ }^{80}$ Later, the abundance of news allowed the Viennese printer Johann van Ghelen to release, in addition to the 'ordinary' avviso, a 24-page booklet with accurate first-hand descriptions of the manoeuvres of the defenders. While apologising for the necessary delay to compose and then print the booklet, the printer explained that his work belonged to another category of news, whose chief selling point was not timeliness of publication, but accuracy and detail. Far from being a small-scale experiment, Van Ghelen's publication was quickly reprinted in several Italian cities: since it was not 'breaking news' in Milan it was released folded in small format and even enhanced with "Aggiunta de' felici progressi dell'armi Christiane" ("The addition of the merry progress of the Christian armies"), thus becoming a book of 186 pages. ${ }^{81}$

Beyond news, the liberation of Vienna stimulated celebratory publications: in 1683 Malatesta published poems, notable among which was a long one with

77 Mario Infelise, 'The War, the News and the Curious: Military gazettes in Italy', in The Politics of Information in Early Modern Europe, ed. Brendan Dooley and Sabina Baron (London: Routledge, 2001), pp. 216-36.

78 Copia di lettera scritta dal campo sotto Vienna (Milan, 1683) was printed by Marco Antonio Pandolfo Malatesta; originally published in Bologna (G. Monti), then reprinted in Rome, Milan, Lucca (S. Marescandoli), Forlì (C. Zampa), Piacenza (G. Bazachi), Genoa (G.B. Franchelli) and Florence (alla Condotta).

79 Distinta relatione della rassegna was reprinted in Modena, Mantua, Genoa and, without title page, in Bologna (1683).

8o Relatione diaria di quanto è seguito nell'assedio della città di Vienna (Milan, 1683).

81 Relazione compendiosa (Vienna, 1683), Relazione compendiosa, e veridica (Venice, 1684), Relazione compendiosa, ma veridica (Bologna, 1684), Vera relazione del combattimento (Macerata, 1684), Narrazione compendiosa, ma veridica (Milan, 1684). 
an avviso layout; and since they were released in the same format, the letters of the King of Poland also became "news matter". 82

Then, following the counter-offensive of the Imperial armies after the siege, the regularity of the information stream enabled serial news to flourish and to acquire periodicity as well. In 1684, in Milan Malatesta published a Giornale dal campo cesareo (Journal from Cesar's Camp), in a regular avviso format (a quarto with title page): though this may have been begun with no fixed seriality in mind, nonetheless it was regularly (re)printed from 10 July to 2 August (at least eight issues were printed, of which three survive). ${ }^{83}$ The following year, Malatesta released another publication with the same name and format (16 known releases, from 30 June to 15 October); then he repeated the publication of Giornali and also of a Ragguaglio in 1686 and 1687, without disdaining to reprint a single-sheet lamento in verse ${ }^{84}$ Apart from the numbering, which was reset to one with each new series, those giornali can be considered as a continuous exceptional stream of news, which simply paused during wintertime, following the rhythm of the campaigns themselves. Milanese giornali suddenly disappeared in 1688 , two years before the Venetian prohibition that decreed the eclipse of this kind of news. ${ }^{85}$ By that time, however, the phenomenon of printed information was definitively consolidated and its patterns established.

82 Vienna assediata dall'armi ottomane (Milan, 1683); it had been already published in Rome, by Michele Ercole (1683). Malatesta's Applauso alla maesta del re di Polonia (Milan, 1683) was a small manifesto with a sonnet. For the King of Poland's letters, see Lettera scritta dalla Sacra Maesta del Re di Polonia alla regina sua consorte (Milan, 1683), Copia di lettera scritta dalla maesta del re di Polonia al padre Marco d'Aviano capuccino (Milan, 1683).

83 Giornale dal campo cesareo sotto Grana li 19. giugno 1684 (Milan, 1684). The title lacked an issue number and declared that it was published as a reply: "Ristampato fedelmente in Milano, con il quale si vede quanto false siano state le notitie diseminate quà il prossimo venerdì scorso, capitate per il Corriere di Bergamo" ("Reprinted accurately in Milan, it shows that the news disseminated here last Friday carried by the Courier of Bergamo is false").

84 Giornale primo [- decimosesto] dal campo cesareo (Milan, 1685); Giornale dal Campo Cesareo (Milan, 1687), 19 unnumbered issues (11 June-10 November); Giornale primo [-trigesimonono] dal campo cesareo (Milan, 1687), 39 issues, 30 March-18 December; Ragguaglio num. 23 dal campo cesareo (Milan, 1687) is uncertain, since only one issue is extant (4 November); Lamento che fa Emerigo Tekeli per esser stato imprigionato in Varadino (Milan, 1685), already printed in Venice, it was published also in Rome.

85 Infelise, 'War, the News and the Curious', p. 232. 